\title{
Peran Media Sosial dalam Upaya Promosi Kesehatan: Tinjauan Literatur
}

\author{
Emy Leonita ${ }^{1^{*}}$, Nizwardi Jalinus ${ }^{2}$ \\ ${ }^{1}$ STIKes Hang Tuah Pekanbaru \\ ${ }^{2}$ Fakultas Teknik, UniversitasNegeri Padang \\ *Corresponding author, e-mail: leonitaemy@yahoo.com
}

\begin{abstract}
Abstrak-Kebutuhan informasi kesehatan yang akurat dan terkini semakin dibutuhkan seiring perkembangan teknologi informasi. Media sosial telah menunjukkan perannya dalam upaya promosi kesehatan di dunia. Untuk itu penelitian ini bertujuan untuk menjawab 1) urgensi pemanfaatan media sosial dalam bidang promosi kesehatan 2) Jenis media sosial yang digunakan dan kelemahannya 3) peran profesional bidang kesehatan melakukan promosi kesehatan berbasis media sosial. Penelurusan jurnal internasional dengan mesin pencarian 1) google scholar 2) since dirrect 3) sage publication 4) elsevier publication. Dari menelusuri 100 jurnal publikasi internasional, 85 jurnal yang relevan dengan topik yang dikelompokan menjadi 35 jurnal pemanfaatan media sosial, 33 jurnal karakteristik media sosial yang digunakan serta kelemahannya dan 17 jurnal peran profesional kesehatan dalam melakukan promosi kesehatan berbasis media sosial. Hasil Penelusuran mengungkapkan media sosial berkontibusi positif terhadap upaya promosi kesehatan, namun beberapa kelemahan antara lain: kurangnya penjangkauan terhadap audien pasif, informasi palsu dan tidak akurat, kurangnya interaksi dengan audien, keterbatasan kemampuan profesional kesehatan memanfaatkan media sosial sehingga tidak menjamin keberlanjutan program. Profesional bidang kesehatan perlu merancang model promosi kesehatan berbasis media sosial dengan mengintegrasikan media sosial dengan strategi promosi kesehatan serta strategi komunikasi kesehatan.
\end{abstract}

Kata kunci : Media Sosial, Promosi Kesehatan

\begin{abstract}
The need for accurate and up-to-date health information is increasingly needed as the development of information technology. Social media has shown its role in health promotion efforts in the world. Therefore, this study aims to answer 1) the urgency of social media utilization in the field of health promotion 2) Type of social media used and its weaknesses 3) the role of health professionals in promoting health based on social media. International journal entry with search engine 1) google scholar 2) since dirrect 3) sage publication 4) elsevier publication. From tracing 100 journals of international publications, 85 journals relevant to topics are grouped into 35 journals of social media utilization, 33 journal characteristics of social media used and their weaknesses and 17 journals the role of health professionals in promoting health-based social media. Search results reveal that social media contribute positively to health promotion efforts, but some weaknesses include: lack of outreach to passive audience, false and inaccurate information, lack of interaction with the audience, limited ability of health professionals to utilize social media so as not to guarantee program sustainability. Health professionals need to design health promotion models based on social media by integrating social media with health promotion strategies and health communication strategies.
\end{abstract}

Keywords: Social Media, Health Promotion.

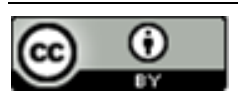

This is an open access article distributed under the Creative Commons 4.0 Attribution License, which permits unrestricted use, distribution, and reproduction in any medium, provided the original work is properly cited. (C2018 by Author and Universitas Negeri Padang

\section{I.PENDAHULUAN}

Perkembangan penyakit merupakan hal yang hampir seimbang bahkan lebih dibandingkan dengan tingkat pertumbuhan penduduk di
Indonesia, setiap detik penduduk di Indonesia terkena penyakit yang belum tentu kita temukan obatnya, setiap individu manusia baru merasakan dirinya mengalami penyakit apabila mengalami gejala-gejala yang mulai mengganggu, tindakan 
yang diambil salah satunya adalah dokter dan Rumah Sakit. Peran Rumah Sakit sebagai salah satu institusi kesehatan belum memadai dalam publikasi informasi tentang kesehatan, meskipun tindakan rumah sakit dalam mempromosikan penyakit dan penanggulangannya sudah dilakukan. Banyak faktor yang tidak diketahui akibat pemberitahuan, publikasi atau segala informasi penyuluhan yang diberikan oleh praktisi atau institusi kesehatan. Seperti halnya penyakit, perkembangan teknologi telah mencapai tingkatan siapa saja,kapan saja dan dimana saja dapat memproleh informasi dengan sangat cepat dan murah. Salah satu media penyampaian informasi secara cepat dengan teknologi merupakan salah satu kehandalan internet sebagai fenomena teknologi, untuk penggunaan media internet.

Kebutuhan akan informasi yang akurat, tepat, dan terkini semakin dibutuhkan seiring dengan perkembangan teknologi informasi yang sangat pesat. Hal ini mendorong masyarakat dan instansi untuk memanfaatkan teknologi informasi tersebut. Informasi yang beragam terlepas dari sifatnya yang dapat bernilai positif atau negatif akan mempengaruhi timbulnya suatu masalah, khususnya masalah kesehatan. Penataan informasi yang dilakukan secara teratur, jelas, tepat, dan cepat serta dapat disajikan dalam sebuah laporan tentunya sangat mendukung kelancaran kegiatan operasional organisasi dan pengambilan keputusan yang tepat. Sekarang ini, website tidak hanya diakses dengan menggunakan browser di desktop, namun juga di akses di tablet ataupun smartphone. Dengan demikian perlu di analisis bagaimana peluang untuk melakukan upaya perubahan perilaku melalui pendidikan kesehatan dan promosi kesehatan dengan menggunakan media online.

\section{Metode}

Penelitian ini merangkum efektivitas media sosial dalam penyebaran informasi kesehatan terutama dalam upaya promosi kesehatan, dengan menjawab pertanyaan berikut:

1. Bagaimana urgensi pemanfaatan media sosial dalam bidang promosi kesehatan?

2. Apa saja jenis media sosial yang digunakan selama ini dan kelemahannya?

3. Bagaimana peran profesional dalam bidang kesehatan melakukan promosi kesehatan berbasis media sosial?

Untuk mendapatkan sumber informasi yang luas terhadap makalah ini, maka penulis melakukan telaah terhadap jurnal yang paling relevan yaitu dengan naskah publikasi internasional yang memiliki inpact factor dengan kata kunci sebagai berikut: Google scholar, LNC Springer (www.springer.com), www.elsevier.com, www.sagepub.com, dan jurnal promosi kesehatan internasional. Penulis memilih jurnal terpublikasi internasional sebagai Kriteria penelusuran jurnal, yang memiliki cakupan topik yang relevan seperti "Media Sosial dan Promosi Kesehatan" serta "Promosi Kesehatan dan Web".

Proses Seleksi yang ditelusuri terhadap 100 jurnal, maka hanya 82 jurnal yang relevan dengan topik. Dari 82 jurnal, dapat dikelompokkan menjadi: 33 jurnal tentang pemanfaatan media sosial dibidang kesehatan,32 jurnal tentang karakterisitik media sosial dalam promosi kesehatan dan kelemahannya dan 17 jurnal tentang peran profesional dalam bidang kesehatan melakukan promosi kesehatan berbasis media sosial.

\section{HASIL DAN PEMBAHASAN}

Media sosial melalui internet $[1,2]$ memiliki potensi besar untuk melakukan promosi kesehatan dan intervensi kesehatan lainnya [3], dan lebih mudah untuk menyentuh sasaran pada setiap levelnya [4-6]. Untuk itu dalam tulisan ini perlu menguraikan secara teoritis tentang: 1) promosi kesehatan dan urgensinya menggunakan media sosial, 2) Karakterisitik media sosial dalam promosi kesehatan dan kelemahannya, 3) peran profesional dalam bidang kesehatan melakukan promosi kesehatan berbasis media sosial

\section{A. Promosi Kesehatan dan Urgensinya Menggunakan Media Sosial}

Menurut WHO, promosi kesehatan adalah proses mengupayakan individu -individu dan masyarakat untuk meningkatkan kemampuan mereka mengandalkan faktor-faktor yang mempengaruhi kesehatan sehingga dapat meningkatkan derajat kesehatannya. Bertolak dari pengertian yang dirumuskan WHO, Indonesia merumuskan pengertian promosi kesehatan adalah upaya untuk meningkatkan kemampuan masyarakat melalui pembelajaran dari, oleh, untuk dan bersama masyarakat agar mereka dapat menolong diri nya sendiri (mandiri) serta mengembangkan kegiatan bersumber daya masyarakat sesuai sosial budaya setempat dan didukung oleh kebijakan publik yang berwawasana kesehatan. Hasil rumusan 
Konferensi Internasional Promosi Kesehatan di Ottawa, Canada menyatakan bahwa promosi kesehatan adalah suatu proses untuk memampukan masyarakat dalam memelihara dan meningkatkan kesehatan mereka. Dengan kata lain, promosi kesehatan adalah upaya yang dilakukan terhadap masyarakat sehingga mereka mau dan mampu untuk memelihara dan meningkatkan kesehatan mereka sendiri [7]. Menggunakan media sosial dapat meningkatkan akses masyarakat terhadap informasi kesehatan, serta mempromosikan perubahan perilaku yang positif, dengan demikian media sosial dapat berkolaborasi [8] dan melengkapi promosi kesehatan yang selama ini masih konvensional [3]. Media sosial dapat menjadi alat yang unggul dengan jangkauan dan interaktivitas luas [9]. Beberapa bukti empiris menemukan hal menarik menggunakan media sosial untuk intervensi pencegahan penyakit seperti penghentian perilaku merokok melalui Tweet dan situs kesehatan [10], video youtube tentang kanker [11-14], peningkatan pengetahuan remaja tentang kesehatan reproduksi, pengetahuan pasien mengenai diabetes $[15,16]$ dan pemahaman mengenai kebugaran dan aktifitas fisik [17-19] melalui facebook [20]. Situs jejaring sosial lainnya yang banyak dikunjungi oleh pencari informasi terkait kesehatan adalah melalui web $[21,22]$ yang memuat informasi tentang kesehatan seksual [23], diet sehat [24], kesehatan ibu hamil $[25,26]$, kesehatan reproduksi remaja putri [27]. Kesehatan komunitas klinis di rumah sakit [28-30] yang berhasil meningkatkan citra rumah sakit yang memanfaatkan media online [31]yang berisi konten tentang gaya hidup sehat bagi pasien [32], kondisi kedaruratan dalam bidang kesehatan $[33,34]$. Promosi kesehatan melalui online juga bisa dapat di aplikasikan ditempat kerja, dimana informasi umumnya adalah tentang kesehatan karyawan [35-37].

Teknologi berupa media sosial memfasilitasi pengetahuan masyarakat yang lebih baik tentang penyakit dan pencegahannya, penggunaan layanan kesehatan yang lebih baik, lebih patuh terhadap pengobatan dan partisipasi dalam keputusan kesehatan [38], peningkatan dukungan sosial serta berbagi dukungan kepada orang lain sehingga masyarakat mampu secara mandiri menyebarluaskan pengalaman positif mereka tentang perubahan perilaku yang lebih sehat $[39,40]$, perubahan tubuh, efek samping penyakit serta dampak positif dari menerapkan gaya hidup sehat. Secara keseluruhan,berdasarkan studi literatur menunjukkan media sosial berkontribusi positif terhadap pencapaian tujuan dari promosi kesehatan [41], sehingga para profesional bidang kesehatan diharapkan mampu berkolaborasi dan mengintegrasikan media sosial dengan strategi promosi kesehatan.

\section{B. Karakteristik Media Sosial dalam Promosi Kesehatan serta kelemahannya}

Era digital yang dikenal dengan Web 2.0 atau Health 2.0 atau Medicine 2.0 [42] menjadikan masyarakat sehat dan pasien lebih mengandalkan Internet daripada dokter sebagai sumber informasi perawatan kesehatan. Situs web media sosial yang populer terbukti efektif dan ampuh untuk menyebarluaskan informasi kesehatan [43-47], mendukung upaya promosi kesehatan [48] dan dapat ditelusuri secara online seperti YouTube, Facebook, MySpace, Twitter, dan Second Life. [49-51] serta image sharing, mobile technology dan blog [52,53]. Berikut pemaparan singkat terhadap media tersebut

\section{Youtube}

Lebih dari 100 juta video dilihat di Youtube setiap hari, dan jumlah itu terus meningkat. Beberapa studi kesehatan masyarakat baru-baru ini telah terlihat video yang dihosting di YouTube tentang vaksinasi papillomavirus dan pesan tembakau serta makanan kaleng "bercacing". Para Peneliti menunjukkan potensi daya yang disimpan YouTube untuk pengambilan keputusan kesehatan secara pribadi [50]

\section{Facebook}

Penggunaan situs jejaring sosial terus berkembang. Situs digunakan oleh jutaan orang setiap hari untuk berinteraksi dan terlibat dengan pengguna lain, untuk berbagi konten dan untuk belajar. Situs jejaring sosial menyediakan cara langsung dan pribadi untuk menyampaikan program, produk, dan informasi. Situs jejaring sosial paling populer adalah Facebook, yang memiliki lebih dari 750 juta pengguna. Pengguna rata-rata menciptakan 90 buah konten setiap bulan, dan $50 \%$ pengguna aktif masuk ke Facebook pada hari tertentu (Facebook, 2011) Facebook merupakan platform publik dan, dalam banyak kasus, menjangkau masyarakat umum. Halaman Facebook yang ditargetkan secara khusus untuk mengatasi layanan kesehatan, profesional kesehatan masyarakat dan lain-lain [53]. Terjadi hubungan positif antara pencari informasi kesehatan [19]. 


\section{Twitter}

Twitter adalah situs mikroblog paling populer di Amerika Serikat dengan lebih dari 305 juta pengguna aktif bulanan (Twitter, 2016). Jangkauannya sangat tinggi di kalangan remaja dan dewasa muda (Duggan, 2015). Batas 140 karakter membuat tweets singkat dan membuat pembaca merespons dengan cepat dan mudah. Pengguna Twitter mengambil peran yang lebih aktif tidak hanya dengan menerima tetapi juga dengan berbagi, mengirim, atau mengirim ulang pesan [53]. Target audiens potensial antara lain adalah siswa sekolah menengah, mahasiswa kesehatan, dosen/guru bidang pendidikan kesehatan dan para profesional kesehatan [54].

\section{Second Life}

Second Life memungkinkan pengguna untuk berinteraksi dengan banyak format, termasuk audio, video, gambar,dan teks, dan membawa masyarakat "bersama-sama" dalam ruang virtual saat mereka berada jauh secara geografis. Dermatologi Second Life? bisa menawarkan pasien sebuah situs dengan pendapat ahli dari seluruh dunia atau grup dukungan online untuk penyakit spesifik [53].

\section{Image Sharing}

Berbagi gambar memberikan nilai untuk kegiatan komunikasi kesehatan dengan menyediakan gambar kesehatan masyarakat yang dapat dengan mudah ditempatkan di situs web, blog, atau situs media sosial lainnya. Karena pembuatan konten terus meningkat di saluran media sosial dan di internet secara keseluruhan, kebutuhan akan grafis segar dan konten yang menarik juga meningkat. Meluasnya penggunaan ponsel dengan kamera membuatnya lebih mudah untuk mengambil foto. Aplikasi seluler untuk foto dan partisipasi yang meledak di jejaring sosial seperti Facebook dan Twitter telah berkontribusi terhadap lonjakan popularitas berbagi foto online. Lebih dari 100 juta foto sehari diunggah ke Facebook. Organisasi dapat memanfaatkan tren ini dengan memberikan gambar visual kepada penggemar dan pengikut yang menunjukkan "tindakan" kesehatan masyarakat, memperkuat pesan kesehatan, atau hanya menyajikan informasi yang ada dalam format baru yang menarik secara visual [53].

\section{Mobile technology}

Ponsel mendukung berbagai fungsi teknis,kebanyakan layanan pesan suara dan pesan singkat (SMS atau pesan teks) memungkinkan komunikasi dua arah secara langsung maupun tidak langsung. Saat ini banyak ponsel memiliki kamera untuk mengambil gambar atau video berdurasi pendek yang dapat dilihat di telepon, diunduh ke salah satu komputer, atau ditransmisikan ke orang lain. Pengolahan data dan kemampuan penyimpanan di ponsel meningkat setiap tahun dan, melalui koneksi jaringan server, mendukung transmisi dan analisis data dalam berbagai bentuk, termasuk teks, file numerik, grafik, audio, dan video seperti "Ponsel pintar". Ponsel dapat mengakses jaringan data nirkabel kapan saja, terkadang ada fitur tambahan radio yang memungkinkan data cepat bertukar melalui internet di beberapa lokasi. Beberapa ponsel dapat berkomunikasi dengan elektronik lainnya melalui penggunaan Bluetooth [54]. Teknologi ponsel menjadi lebih kuat dan lebih murah, dengan bukti mulai muncul pengiriman layanan perawatan kesehatan dan promosi kesehatan pribadi melalui ponsel [55-57].

Blog

Blog merupakan singkatan dari web log adalah bentuk aplikasi web yang berbentuk tulisantulisan (yang dimuat sebagai posting) pada sebuah halaman web. Tulisan-tulisan ini seringkali dimuat dalam urutan terbalik (isi terbaru dahulu sebelum diikuti isi yang lebih lama), meskipun tidak selamanya demikian. Situs web seperti ini biasanya dapat diakses oleh semua pengguna Internet sesuai dengan topik dan tujuan dari si pengguna blog tersebut [53].

Bukti empiris menunjukkan pemanfaatan media sosial diatas efektif dalam melakukan upaya promosi kesehatan dengan tujuan meningkatkan pemahaman dan memberi dukungan kepada masyarakat untuk berperilaku sehat, namun tidak dapat dipungkiri, dibalik kesuksesan media tersebut terdapat beberapa kelemahan [58]. Pertukaran informasi perlu dimonitor, dievaluasi dan ditinjau ulang untuk kualitas dan keandalan dari informasi [59]. Evaluasi yang kuat dan komprehensif, menggunakan berbagai metodologi dibutuhkan untuk menetapkan apakah media sosial tersebut meningkatkan praktik promosi kesehatan baik dalam jangka pendek maupun jangka panjang. Mengukur dampak media, biaya media sosial, manfaat dan efektifitas sebagai alat promosi kesehatan [9].

Penelusuran publikasi internasional ditemukan beberapa kelemahan dan hambatan media sosial yang digunakan dalam upaya promosi kesehatan, antara lain: 
1. Studi yang dilakukan dibeberapa negara berkembang menunjukkan bahwa pencari informasi bersifat pasif daripada aktif, sehingga informasi yang disebarluaskan tidak seluruhnya dapat diakses oleh masyarakat [60] serta kurangnya akses masyarakat yang tidak terhubung dengan jaringan [61].

2. Informasi kesehatan yang diperoleh melalui web dengan cepat dan mudah bisa menyebabkan ketidakseimbangan informasi [62], karena semua pihak dapat memasukkan informasi walaupun tidak memiliki kompetensi dibidang kesehatan. Hal ini tentu saja berpotensi bahaya akibat kelebihan konsumsi informasi [61]. Masyarakat juga harus diberi informasi tentang informasi yang tesedia apakah layak untuk mereka telusuri [63].

3. Informasi yang terdapat di media sosial, beberapanya teridentifikasi berita palsu [64] dan tidak akurat [65] Masyarakat kesulitan dan kebingungan dengan informasi yang diperoleh [61], sehingga berkontribusi terhadap perilaku kesehatan yang negatif dan hasil kesehatan yang buruk pula [66]. Konten yang terdapat di media sosial perlu diperjelas lagi oleh pihak berwenang [67] agar masyarakat dapat memilih informasi yang akurat.

4. Kurang maksimalnya pemanfaatan media sosial oleh profesional kesehatan karena terbatasnya kemampuan dalam mengelola informasi kesehatan berbasis media sosial [68].

5. Minimnya interaktif antara pencari informasi dengan profesional kesehatan sehingga masyarakat tidak tertarik untuk mengunjungi situs tersebut yang mengakibatkan ketidakberlanjutan program promosi kesehata di media sosial [69].

\section{Peran profesional dalam bidang kesehatan melakukan promosi kesehatan berbasis media sosial}

Perubahan perilaku kesehatan yang tidak menurun secara signifikan merupakan pandangan pesismis untuk mengadopsi potensi media sosial untuk promosi kesehatan [58]. Pandangan tersebut perlu dimimalisir dengan meningkatkan peran profesional bidang kesehatan dalam meningkatkan kualiatas promosi kesehatan berbasis media [70]. Peran profesional tersebut antara lain :

1. Adopsi konsep media sosial yang telah berhasil di bidang bisnis. Saran memanfaatkan media sosial tersebut adalah [71] 1) identifikasi media dengan hati-hati, 2) pilih aplikasi atau buat sendiri, 3) pastikan keselarasan aktifitas di media sosial, 4) integrasi rencana media dan 5) akses untuk semua. Kesuksesan penerapan aplikasi tersebut dengan meluangkan waktu untuk meninjau interaksi/percakapan dan mendedikasikan waktu untuk menanggapi tanggapan audien [72].

2. Menggabungkan media sosial dengan strategi pemasaran sosial dengan 4 langkah [73]: 1) jelaskan audien, 2) tuliskan tujuan untuk terlibat dengan audien, 3) buat garis besar strategi khusus untuk melibatkan dan 4) pilih teknologi.

3. Mengembangkan rencana komunikasi strategis dengan menggabungkan media sosial dengan praktek dilapangan untuk memperluas jangkauan dan mendorong interaktivitas dan keterlibatan $[74,75]$.

4. Profesional kesehatan perlu mempertimbangkan dampak terbaik dan terburuk dari konten yang mereka sampaikan di media sosial [76] serta mempertimbangkan sinergi antara media sosial dan promosi kesehatan [77].

5. Organisasi dan praktisi promosi kesehatan harus dapat mencocokkan kebutuhan program dengan hasil yang diberikan oleh media sosial dengan melakukan evaluasi secara komprehensif $[78,79]$, dengan kerangka kerja evaluasi proses dan evaluasi dampak [80].

6. Mengembangkan intervensi dengan membentuk tim multidisiplin, menjamin ketersediaan sumber daya untuk mempertahankan kehadiran online serta interaksi dua arah merupakan fitur baru promosi kesehatan dengan media sosial [80].

7. Mengidentifikasi dan memilih konten dengan isu-isu terkini dengan mempertimbangkan berbagai pemangku kepentingan [81].

8. Profesional kesehatan dapat mengadopsi 3 cara penggunaan internet untuk meningkatkan kesehatan masyarakat: 1) menggunakan format wiki untuk pengetahuan dasar seperti "wikihealth" untuk komunitas yang membutuhkan informasi/pengetahuan, 2) membentuk organisator komunitas seperti model MySpace, 3) menggunakan blog untuk bertukar informasi [82].

9. Memaksimalkan paparan informasi dengan basis bukti yang kuat, dengan mempertimbangkan konten relevan untuk audien yang tepat atau bahkan berbeda [49] serta memperjelas peran profesional dalam memfasilitasi media sosial [83-86]. 


\section{KESIMPULAN}

Kebutuhan akan informasi yang akurat, tepat, dan terkini semakin dibutuhkan seiring dengan perkembangan teknologi informasi yang sangat pesat terutama di bidang kesehatan. Media sosial melalui internet memiliki potensi besar untuk melakukan promosi kesehatan dan intervensi kesehatan lainnya, dan lebih mudah untuk menyentuh sasaran pada setiap levelnya. Bukti empiris menunjukkan pemanfaatan media sosial efektif dalam melakukan upaya promosi kesehatan dengan tujuan meningkatkan pemahaman dan memberi dukungan kepada masyarakat untuk berperilaku sehat, namun tidak dapat dipungkiri, dibalik kesuksesan media tersebut terdapat beberapa kelemahan. Solusi terhadap kelemahan tersebut dengan meningkatkan peran profesional bidang kesehatan dalam mengelola promosi kesehatan berbasis media sosial, sehingga informasi lebih berkualitas.

Profesional kesehatan dapat melakukan langkah-langkah berikut: mengidentifikasi audien, memilih konten yang tepat, memilih strategi yang dapat diadopsi dari bidang lain seperti bidang bisnis, memberikan informasi berbasis data yang akurat dan terkini, meningkatkan partisipasi audien dan penyedia layanan, melakukan monitoring dan evaluasi guna memastikan program promosi berhasil dan berkelanjutan secara online

\section{DAFTAR PUSTAKa}

[1] Barakhsanova, E.A et. al (2016) Internet Access and Youth of Yakutia Awareness on the HealthPromotion Factor. International Journal Of Environmental \& Science Education Vol.11, No.18, 11477-11484

[2] Wangberg, Silje C. et.al (2007) Relations between Internet use, socio-economic status (SES), social support and subjective health. Health Promotion International, Vol. 23 No. 1 doi:10.1093/heapro/dam039 Advance Access published 13 December 2007

[3] Levac \& Sullivan (2018) Interactive social media interventions for health behaviour change, health outcomes, and health equity in the adult population Cochrane Database of Systematic Reviews 2018, Issue 2. Art. No.: CD012932: doi:10.1002 /14651858 .CD012932. www.cochranelibrary.com

[4] Flora, J. A., \& Maibach, E. W. (2000) The Role Of Media Across Four Levels Of Health Promotion Intervention. Annu. Rev. Public Health 1989.10:181-201

[5] Pálsdóttir, Ágústa (2014) Preferences in the use of social media for seeking and communicating health and lifestyle information. Information Research, 2014, 19(4) paper 642.

[6] Tezci, Erdoğan \& İçen , Mustafa (2014) High School Students' Social Media Usage Habits. Journal of Education and Practice www.iiste.org ISSN 2222-1735 (Paper) ISSN 2222-288X (Online) Vol.8, No.27, 2017

[7] Notoatmodjo, S. (2010).Promosi Kesehatan Teori \& Aplikasi. Edisi Revisi. Jakarta: Rineka Cipta

[8] Bacigalupe, Gonzalo (2011) Is There a Role for Social Technologies in Collaborative Healthcare?. Families, Systems, \& Health, 2011, Vol. 29, No. 1, 1-14 DOI: $10.1037 / \mathrm{a} 0022093$

[9] Korda \& Itani (2013) Health Promotion Practice, Downloaded from hpp.sagepub.com : DOI: 10.1177/1524839911405850 January 2013 Vol. 14, No. 1 15-23

[10] Skinner ,Harvey A. et.al (2006) Developing Internet-Based eHealth Promotion Programs: The Spiral Technology Action Research (STAR) Model Health Promotion Practice DOI: $10.1177 / 1524839905278889$ Published by :http:// www. Sagepublications .com October 2006 Vol. 7, No. 4, 406-417

[11] Sylvia Chou et.al (2013) Web 2.0 for Health Promotion: Reviewing the Current Evidence. American Journal of Public Health, January 2013, Vol 103, No. 1

[12] Lapointe et.al (2013) Collaborating through Social Media to Create Health Awareness. 2013 46th Hawaii International Conference on System Sciences : doi 10.1109/HICSS.2013.135

[13] Lapointe et.al (2014) Creating health wareness: a social media enabled collaboration. Received: 1 August 2013 /Accepted: 5 December 2013: DOI 10.1007/s12553-013-0068-1C IUPESM and Springer-Verlag Berlin Heidelberg

[14] Chung. J. E (2017) Retweeting in health promotion: Analysis of tweets about Breast Cancer Awareness Month. Computers in Human Behavior doi:10.1016 /j.chb.2017.04.025

[15] Rider, B. B. Et.al (2016), Interactive WebBased Learning Translating Health Policy Into Improved Diabetes Care. American Journal of Preventive Medicine, 2016;50(1): 122-128 http://dx.doi.org/10.1016/j.amepre.2015.07.038 Published by Elsevier Inc. on behalf of American Journal of Preventive Medicine

[16] AlQarn , Z.A., et.al (2016) Health information sharing on Facebook:An exploratory study on diabetes mellitus. Journal of Infection and Public Health (2016) 9, 708-712 http://dx.doi.org/10.1016/j.jiph.2016.08.015187 6-0341/C 2016 King Saud Bin Abdulaziz University for Health Sciences. Published by Elsevier Limited 
[17] Frimming et.al (2011) Evaluation of a Health and Fitness Social Media Experience. Global Health Promotion 1757-9759; Vol 19(4): 3-6

[18] Schoenfelder,Erin et.al (2017) Piloting a mobile health intervention to increase physical activity for adolescents with ADHD. Preventive Medicine Reports 6 (2017) 210-213 http://dx.doi.org/10.1016/j.pmedr.2017.03.0032 211-3355/C 2017 The Authors. Published by Elsevier Inc.

[19] Oh, Hyun Jung et.al (2013) Facebooking for health: An examination into the solicitation and effects of health-related social support on social networking sites. Computers in Human Behavior 29 (2013) 2072-2080 Elsevier http: //dx.doi.org /10.1016/ j. chb. 2013.04.017

[20] Andrizal, A., \& Arif, A. (2017). Pengembangan Media Pembelajaran Interaktif Pada Sistem ELearning Universitas Negeri Padang. Invotek: Jurnal Inovasi Vokasional Dan Teknologi, 17(2), 1-10

[21] Cuéllar, M.M.G et.al (2013) Web Tools 2.0 for Health Promotion in Mexico. Journal of Applied Research and Technology, Vol. 11, October 2013

[22] Liang, Huigang. et.al (2006) Web-based intervention support system for health promotion. Decision Support Systems 42 (2006) 435-449 doi:10.1016/j.dss.2005.02.001 see front matter D 2005 Elsevier

[23] Gold, Judy et.al (2011) A systematic examination of the use of Online social networking sites for sexual health promotion. BMC Public Health 2011, 11:583 http://www.biomedcentral.com/14712458/11/583

[24] McKinley C. J. \& Wright, P. J (2014) Informational social support and online health information seeking: Examining the association between factors contributing to healthy eating behavior. Computers in Human Behavior 37 (2014) 107-116 http://dx.doi.org/10.1016/j.chb.2014.04.023074 7-5632/2014 Elsevier Ltd

[25] Chedid, R. A. et.al (2017) Best practices for online Canadian prenatal health promotion: A public health approach. WOMBI 725 No. of Pages 9 https://doi.org/ 10.1016/j.wombi.2017 .10.0051871-5192/C 2017 Australian College of Midwives. Published by Elsevier Ltd

[26] Kennedy, R.A.K. et.al (2017) Preferences of women for web-based nutritional information in pregnancy. Public Health 143 (2017) 71-77 http://dx.doi.org /10.1016 /j.puhe.2016 .10.0280033-3506/C 2016 The Royal Society for Public Health. Published by Elsevier Ltd

[27] Schwinn, Traci M. et. al (2014) A web-based, health promotion program for adolescent girls and their mothers who reside in public housing.
Journal of Applied Research and Technology, Vol. 11, October 2013

[28] Auefuea, Suchitra et.al (2016) Development of electronic home health care record system on web applications. Procedia Computer Science $86 \quad$ (2016) $204 \quad-\quad 207 \quad$ doi: 10.1016/j.procs.2016.05.066 Published by Elsevier

[29] Kang, Ji Soon et.al (2014) A Web-based Health Promotion Program for Patients with Metabolic Syndrome. Asian Nursing Research 8 (2014) $82 \mathrm{e} 89$

http://dx.doi.org/10.1016/j.anr.2014.03.0021976 -1317/Copyright 2014, Korean Society of Nursing Science. Published by Elsevier

[30] Kreps, G. L. \& Neuhau, L (2010) New directions in eHealth communication: Opportunities and challenges. Patient Education and Counseling 78 (2010) 329-336 Published by Elsevier Ireland Ltd doi:10.1016/j.pec.2010.01.013

[31] Kristopher , Lewis \& Reicher. Murray A. (2016) Web Applications for Patient Communication. Journal of the American College of Radiology. http://dx.doi.org/10.1016/j.jacr.2016.09.013Vol ume 13, Number 12PB

[32] Neubeck, Lis et.al (2016) Development of an integrated e-health tool for people with, or at highrisk of, cardiovascular disease: The Consumer Navigation of Electronic Cardiovascular Tools (CONNECT) web application. International Journal of Medical Informatics, (2016) http://dx.doi.org/10.1016/ j.ijmedinf.2016.01.0091386-5056/C 2016 Published by Elsevier Ireland Ltd

[33] Merchant et.al (2011) Integrating Social Media into Emergency-Preparedness Efforts. The New England Journal of Medicine, july 28, 2011, 365;4:http://hpp.sagepub.com/content/13/2/165 : DOI: $10.1177 / 1524839911432009$

[34] Merchant, R.M.,et.al (2011) Integrating Social Media into Emergency-Preparedness Efforts, The New England Journal of Medicine 365;4 nejm.org july 28, 2011 Downloaded from nejm.org on March 21, 2018

[35] Melzner, J et.al (2014) Mobile health applications in workplace health promotion: an integrated conceptual adoption framework. Procedia Technology 16 (2014) 1374 - 1382 doi: 10.1016/j.protcy.2014.10.155 Published by Elsevier Ltd.

[36] Robroek , Suzan JW et.al (2009) Determinants of participation in worksite health promotion programmes: a systematic review. International Journal of Behavioral Nutrition and Physical Activity 2009, 6:26 doi:10.1186/1479-5868-626

[37] Mhurchu, C.N et,al (2010) Effects of worksite health promotion interventions on employee 
diets: a systematic review. BMC Public Health 2010, $10: 62$ http://www.biomedcentral.com/1471$2458 / 10 / 62$

[38] Ortega, C \& Navas (2017) The use of new technologies as a tool for the promotion of health education. Procedia - Social and Behavioral Sciences 237 ( 2017 ) 23 - 29 doi: 10.1016/j.sbspro.2017.02.006 Published by Elsevier Ltd

[39] Cutrona, Sarah L et,al (2015) Health information seeking on behalf of others: Characteristics of 'surrogate seekers'. J Cancer Educ. 2015 March ; 30(1): 12-19 : doi:10.1007/s13187-014-0701-3.

[40] Bergsma, Lynda J. (2004) Empowerment Education The Link Between Media Literacy and Health Promotion. American Behavioral Scientist, Vol. 48 No. 2, October 2004 152-164 DOI: $10.1177 / 0002764204267259 \Subset 2004$ Sage Publications

[41] Covolo, L. et.al (2017) Does evidence support the use of mobile phone apps as a driver for promoting healthy lifestyles from a public health perspective? A systematic review of Randomized Control Trials. Patient Education and Counseling, 5763 No. of Pages 13 http://dx.doi.org/10.1016/j.pec.2017.07.0320738 -3991 Elsevier B.V

[42] Van, D. B ,et al (2010) Definition of Health 2.0 and Medicine 2.0:A Systematic Review. Journal Of Medical Internet Research, 2010;12(2):e18 doi:10.2196/jmir. 1350

[43] Sharma Pallavi \& Kaur P.D (2017) Effectiveness of web-based social sensing in health information dissemination - A review. Telematics and Informatics 34 (2017) 194-219 http://dx.doi.org/10.1016/j.tele.2016.04.012073 6-5853/ 2016 Elsevier Ltd

[44] Mano, Rita S. (2014) Social media and online health services: A health empowerment perspective to online health information. Computers in Human Behavior 39 (2014) 404412 http://dx.doi.org/10.1016/j.chb.2014.07. 0320747-5632/ 2014 Elsevier Ltd.

[45] Han, Lu. et.al (2018) The social network of international health aid. Social Science \& Medicine 10.1016/j.socscimed.2018.04.003

[46] Kotsenas , A. L. et.al (2017) The Strategic Imperative for the Use of Social Media in Health Care. American College of Radiology, 2017 https: //doi.org /10.1016/ j.jacr.2017.09.027

[47] Oh , Sanghee \& Kim, Soojung (2014) College students' use of social media for health in the USA and Korea. Information Research Journal VOL. 19 NO. 4

[48] O'mara, Ben (2012) Social media, digital video and health promotion in aculturally and linguistically diverse Australia. Health
Promotion International, Vol. 28 No. 3 doi:10.1093/heapro/das014\# The Author (2012). Published by Oxford University Press. All rights reserved.Advance Access published 30 March, 2012

[49] CDC ((2011) The Healt Comunicator Toolkit

[50] Vance, Karl,et.al (2008) Social Internet Sitesas a Source of Public Health Information. Dermatol Clin $27 \quad$ (2009) 133-136 doi:10.1016/j.det.2008.11.0100733-8635/08 see front Elsevier Inc.

[51] Norman, C.D. (2012) Social media and health promotion. Global Health Promotion 17579759; Vol 19(4): 3-6; 464593. 2012

[52] Moorhead, S.A (2014) Social media and health promotion. Global Health Promotion 17579759; Vol 19(4): 3-6; 464593

[53] CDC (2011) The Health Communicator's Social Media Toolkit. Office Of The Associate Director For Communication

[54] Fettrow, Elizabeth A.(2016) Health Education in the Twitosphere: Will You Follow?. Journal of Health Education Teaching, 2016; 7(1): 1522

[55] Bert, Fabrizio et.al (2014) Smartphones and Health Promotion: A Review of the Evidence. J Med Syst (2014) 38:9995 DOI 10.1007/s10916013-9995-7 \# Springer Science+Business Media New York 2013

[56] Patrick, Kevin,et.al (2008) Health and the Mobile Phone. American Journal of Preventive Medicine, 2008;35(2) see front matter 177C 2008 American Journal of Preventive Medicine Published by Elsevier Inc. doi:10.1016/j.amepre. 2008.05.001

[57] Atienza, A. A., \& Patrick, Kevin, ((2011) Mobile Health The Killer App for Cyberinfrastructure and Consumer Health. American Journal of Preventive Medicine, 2011;40(5S2):S151-S153 doi: 10.1016/j.amepre.2011.01.008 Published by Elsevier Inc

[58] Evers, Kerry E. et.al (2006) eHealth Promotion: The Use of the Internet for Health Promotion. The Art of Health Promotion, March/April

[59] Moorhead, S Anne . et.al (2013) A New Dimension of Health Care: Systematic Review of the Uses, Benefits, and Limitations of Social Media for Health Communication. Journal Of Medical Internet Research, 2013;15(4):e85 doi:10.2196/jmir.1933

[60] Gavgani et.al (2013) Health Information Seeking Behavior (HISB) of people and some related factors; a study in developing country. Library Philosophy and Practice (e-journal). 902.http://digitalcommons.unl.edu/libphilprac/9 02

[61] Benigeri, Mike \& Pluye, Pierre (2010) Shortcomings of Health Information On The 
Internet. Health Promotion International Vol. 18. No. 4 doi: 10.1093/heapro/dag409

[62] Jacobs et.al (2017) Health information seeking in the digital age: An analysis of health information seeking behavior among US adults. Cogent Social Sciences (2017), 3: 1302785: http://dx.doi.org/10.1080/23311886.2017.13027 85

[63] Loss, Julika et.al (2014) Online social networking sites-a novel setting for health promotion?. Health \& Place 26 161-170 http://dx.doi.org /10.1016/j.healthplace. 2013 .12.012 Published by Elsevier Ltd

[64] Waszak ,P.M. et.al (2018) The spread of medical fake news in social media - the pilot quantitative study. Health Policy and Technology (2018), doi: 10.1016 /j.hlpt.2018.03.002

[65] Cline, R.J.W. \& Haynes K.M. (2001) Consumer Health Information Seeking on the Internet: The State Of the Art. Health Education Research, Vol.16. No.6, 2001 Page 671-692

[66] Hagg,Emily, et.al (2018) The emerging use of social media for health-related purposes in low and middle-income countries: A scoping review. International Journal of Medical Informatics $\quad 115 \quad$ (2018) 92-105 https://doi.org/10.1016/j.ijmedinf. 2018.04.01 2018 Published by Elsevier

[67] Steiner, R. J. et.al (2018) Do Health Promotion Messages Integrate Unintended Pregnancy and STI Prevention? A Content Analysis of Online Information for Adolescents and Young Adults. an international reproductive health journal contraception, doi:10.1016/j.contraception.2018 .04 .011

[68] Brusse, Carl et.al (2014) Social Media and Mobile Apps for Health Promotion in Australian Indigenous Populations: Scoping Review. Journal Of Medical Internet Research 2014|Vol.16|Iss.12|E280|P.1 Doi:10.2196/jmir. 3614

[69] Boyington , A.R. et.al (2003) Analysis of Interactive Continence Health Information on the Web. J WOCN 2003;30:280-6 doi: 10.1067/mjw.2003.

[70] Kamel M.N.B \& Wheeler, Steve (2007) The emerging Web 2.0 social software: an enabling suite of sociable technologies in health and health care education. Health Information and Libraries Journal, 24, pp.2-23

[71] Kaplan \& Haenlein (2010) Users of the world, unite! The challenges and opportunities of Social Media Business Horizons 53, 59-68, www.elsevier.com/locate/bushor: doi:10.1016/j. bushor.2009.09.003

[72] Edosomwan, Simeon et.al (2011) The History of Social Media and its Impact on Business. The Journal of Applied Management and Entrepreneurship, 2011, Vol. 16, No.3
[73] Thackeray et. al (2012) Integrating Social Media and Social Marketing: A Four-Step Process. Health Promotion Practice, March 2012 Vol. 13, No. 2 165-168

[74] Norman, Cameron D (2015) Social media and health promotion. Global Health Promotion 1757-9759; Vol 19(4): 3-6

[75] Thackeray et.al (2012) Adoption and use of social media among public health departments. BMC Public Health 2012, 12:242

[76] Greysen, S. Ryan et.al (2010) Online Professionalism and the Mirror of Social Media. J Gen Intern Med 25(11):1227-9 DOI: $10.1007 / \mathrm{s} 11606-010-1447-1$ C Society of General Internal Medicine

[77] Zhou, Lina, et.al (2018) Harnessing social media for health information management. Electronic Commerce Research and Applications $27 \quad$ (2018) 139-151 https://doi.org/10.1016/j.elerap.2017.12.003156 7-4223/ 2018 Elsevier B.V

[78] Neiger, Brad L.et al (2012) Use of Social Media in Health Promotion: Purposes, Key Performance Indicators, and Evaluation Metrics. Health Promotion Practice Vol. 13, No. 2 159164

[79] Hanson ,Carl, et.al (2011) Use and Acceptance of Social Media among Health Educators. American Journal of Health Education July/August 2011, Volume 42, No. 4

[80] Gold, Judy et.al (2012) Developing Health Promotion Interventions on Social Networking Sites: Recommendations from The FaceSpace Project. Journal of medical internet research, 2012 | vol. 14 iss. 1 e 30 | p.1 doi:10.2196/jmir.1875

[81] Haluza, D \& Jungwirth, D (2014) ICT and the future of health care: aspects of health promotion. International Journal of Medical Informatics $84 \quad\left(\begin{array}{llllll}2 & 0 & 1 & 5 & \text { ( } & 48-57\end{array}\right.$ http://dx.doi.org/10.1016/j.ijmedinf.2014.09.005 1386-5056/C Elsevier Ireland

[82] Crespo, Richard (2007) Virtual Community Health Promotion. Preventing chronic desease (public helath research, practice, and policy) volume 4, No. 3 July 2007. http://www.cdc.gov/pcd/issues/2007/jul/07_004 3.htm.

[83] Hardiker , N. R, \& Grant, M.J (2010) Barriers and facilitators that affect public engagement with eHealth services. (C) 2010 IMIA and SAHIA..MEDINFO 2010C. Safran et al. (Eds.)IOS Press, 2010 doi:10.3233/978-160750-588-4-13

[84] Flynn,Donal, et.al (2009) Expectations and experiences of eHealth in primary care: A qualitative practice-based investigation. international journal of medical informatics 78 (2009) 588-604 see front matter (C) 2009 
Elsevier Ireland Ltd. All rights reserved.doi:10.1016/j.ijmedinf.2009.03.008

[85] Hardiker,N. R. \& Grant M. J. (2011) Factors that influence public engagement with eHealth: A literature review. international journal of medical informatics 80 (2011) 1-12 see front matter (C) 2010 Elsevier Ireland Ltd. All rights reserved. doi:10.1016/j.ijmedinf.2010.10.017

[86] Marlina H, Jalinus N, Rahmat R. Pendidikan Kesehatan Reproduksi Bagi Remaja (Literatur Review). INVOTEK: Jurnal Inovasi Vokasional dan Teknologi. 2018 Jul 9;18(1):83-90.

\section{Biodata Penulis}

Emy Leonita, lahir di Dumai, 9 Desember 1980. Menyelesaikan pendidikan S2 di Program Studi Kesehatan Masyarakat Universitas Gadjah Mada Yogyakarta. Dosen di Stikes Hang Tuah Pekanbaru dan sedang menyelesaikan pendidikan doktoral di Fakultas Tehnik jurusan Pendidikan Teknologi Kejuruan Universitas Negeri Padang

Nizwardi Jalinus, lahir di Palembang, pada 22 Agustus 1952. Saat ini aktif sebagai dosen sekaligus ketua Prodi Pasca Sarjana Program Doktor di Fakultas Teknik jurusan Pendidikan Teknologi Kejuruan Universitas Negeri Padang 